\title{
Correction: A parsimonious approach for large-scale tracer test interpretation
}

\section{Vincent Bailly-Comte ${ }^{1,2}(\mathbb{D}) \cdot$ Séverin Pistre ${ }^{3}$}

Published online: 31 July 2021

(C) Springer-Verlag GmbH Germany, part of Springer Nature 2021

Correction: Hydrogeology Journal (2021) 29:1539-1550 https://doi.org/10.1007/s10040-021-02327-x

Equation (10) should be corrected to:

$m=\frac{\ell Q C k}{R V p}$

Where the added $V\left[\mathrm{~L} \mathrm{~T}^{-1}\right]$ represents the (microscopic) flow velocity, as defined earlier in the paper.

Publisher's note Springer Nature remains neutral with regard to jurisdictional claims in published maps and institutional affiliations.

The online version of the original article can be found at https://doi.org/ 10.1007/s10040-021-02327-x

\footnotetext{
Vincent Bailly-Comte

v.bailly-comte@brgm.fr

1 BRGM, Univ Montpellier, Montpellier, France

2 G-eau, UMR 183, INRAE, CIRAD, IRD, AgroParisTech, Supagro, BRGM, Montpellier, France

3 Hydrosciences Laboratory, Montpellier University, CNRS, IRD, Montpellier, France
} 